\title{
ЮВІЛЕЙ
}

\section{ДО ЮВІЛЕЮ ВИДАТНОГО УКРАЇНСЬКОГО ВЧЕНОГО Ю. І. ГУБСЬКОГО}

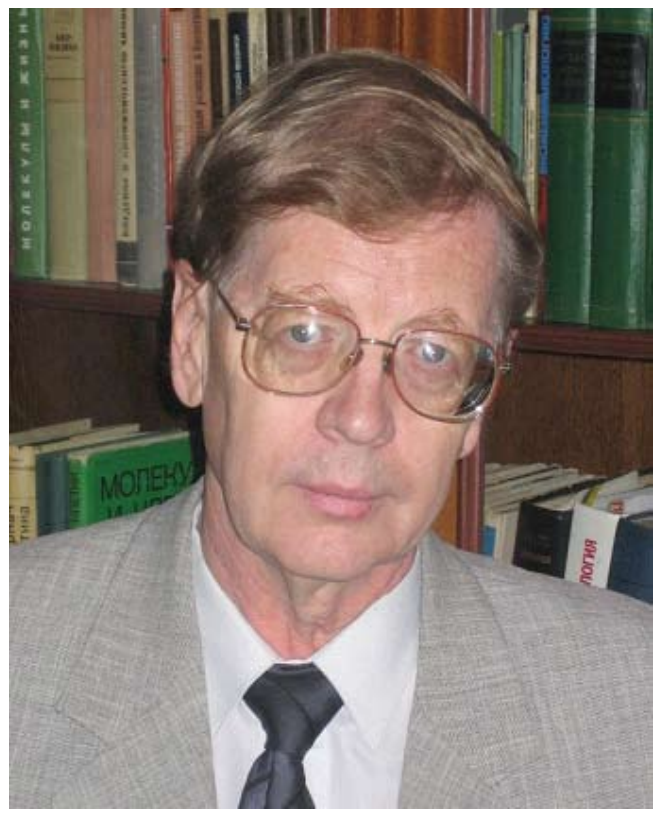

Провідному українському вченому в галузі медичної біохімії і біохімічної фрармакології та токсикології фрізіологічно активних сполук, члену-кореспонденту НАМН України, заслуженому діячу науки і техніки України, доктору медичних наук, професору, головному редактору журналу “Медична та клінічна хімія" Юрію Івановичу Губському 1 жовтня 2015 р. виповнилося 70 років.

Профресор Ю. І. Губський у 1969 р. з відзнакою закінчив лікувальний фракультет Київського медичного інституту імені О. О. Богомольця (на даний час-Національний медичний університет імені О. О. Богомольця), його ім'я занесено в Золоту книгу пошани КМІ. Протягом багатьох років науково-педагогічна діяльність Юрія Івановича пов'язана саме з цим провідним вищим медичним навчальним закладом держави, де він пройшов шлях від аспіранта до профресора, завідувача Центральної науково-дослідної лабораторії (1986-1987), завідувача кафедри біоорганічної, біологічної та фрармацевтичної хімії (1997-2010).

З 1987 до 1992 р. Ю. І. Губський працював заступником директора з наукової роботи і в.о. директора Київського НДІ фрармакології та токсикології МОЗ України (на даний час - Інститут орармакології та токсикології НАМН України), заснував відділ біохімічної фрармакології ІФТ, де розпочав розробку фундаментальних питань щодо пошкодження клітин за дії ксенобіотиків фроссрор- та хлорорганічного походження.
З 1991 р. Юрій Іванович проводив адміністративну та науково-організаційну роботу в МО3, ВАК і НАМН України: заступник голови Вченої медичної ради МОЗ України (1991-1992), начальник управління та атестаційного відділу медичних, біологічних, хімічних і аграрних наук ВАК (1992-2000), член Президії ВАК України (1992-1997), член Президії НАМН України (1992-1997), перший головний вчений секретар (1993-1996).

Беззаперечним визнанням наукових заслуг Ю. І. Губського стало його обрання в 1994 р. членом-кореспондентом НАМН України. Юрію Івановичу як одному із засновників ВАК України за визначний особистий внесок у створення національної системи атестації наукових та науково-педагогічних кадрів вищої кваліфікації в Україні в 1997 р. було присвоєно почесне звання заслуженого діяча науки і техніки України.

Як науковець Ю. І. Губський є учнем та послідовником таких видатних українських учених, як один із перших представників школи академіка О. В. Палладіна член-кореспондент АН УРСР А. М. Утевський, доктор біологічних наук, професор Є. Ф. Шамрай, доктор біологічних наук, професор М. Д. Курський. Основними напрямками його багаторічних наукових досліджень стали вивчення молекулярних механізмів пошкодження біомембран та геному клітин печінки і головного мозку, наукове обґрунтування біохімічних та фрармакологічних ефектів антиоксидантів.

Ю. І. Губський та його учні зробили великий науковий внесок у проблему біохімії оксигеназних та вільнорадикальних реакцій у біологічних системах, розв'язання молекулярних механізмів ураження мембран і генетичного апарату клітини за умов активації вільнорадикальних процесів. Пріоритетним напрямком діяльності вченого та наукової школи, яку він очолює, є цикл робіт, присвячених дослідженням апоптотичної загибелі клітин при пошкодженні ДНК високотоксичними біоцидними ксенобіотиками, вивченню реакцій ліпопереокиснення в ядерному хроматині, ролі іонів кальцію в порушенні метаболічних процесів при антиоксидантній недостатності й дії високотоксичних фрізіологічно активних сполук. На сьогодні Ю. І. Губський розробляє питання щодо комп'ютерного моделювання біохімічних реакцій, квантово-хімічних механізмів дії антиоксидантів, історії біохімічної науки. 
Як завідувач кафедри біоорганічної, біологічної та фрармацевтичної хімії Національного медичного університету імені О. О. Богомольця Ю. І. Губський зробив незаперечний внесок у підвищення рівня наукової і навчальної роботи на кафедрі, він $€$ одним із фрундаторів фрармацевтичного фракультету НМУ, створивши разом з очоленим ним педагогічним колективом методичну базу та розпочавши викладання таких дисциплін, як органічна хімія, фрармацевтична хімія, токсикологічнахімія, іпідготовку спеціалістів та магістрів 3 фрармації.

Ю. І. Губський - автор перших україномовних підручників для студентів вищих медичних та фрармацевтичного навчальних закладів III-IV рівнів акредитації: "Біологічна хімія", “Біоорганічна хімія", "Bioorganic Chemistry" і навчальних програм для вищих навчальних закладів держави з цих дисциплін.

Член-кореспондент НАМН України Ю. І. Губський є автором близько 650 наукових робіт, у тому числі широко відомих наукових монограсрій та довідників, зокрема: "Коррекция химического поражения печени" (1989), "Химические катастрофы и экология" (1993), “Лекарственные средства в психофрармакологии” (1997), "Фармакотерапія в паліативній та хоспісній медицині” (2012), “Смерть клетки: свободные радикалы, некроз, апоптоз" (2015). Під його науковим керівництвом підготовлено 19 докторських та 11 кандидатських дисертацій з біохімії, срармакології і токсикології. Відомими українськими вченими та організаторами медичної науки і вищої медичної освіти $€$ такі учні Юрія Івановича, як доктор біологічних наук, профресор Г. М. Ерстенюк, доктор медичних наук, професор В. М. Ждан, доктор біологічних наук $€$. Л. Левицький, доктор медичних наук Н. В. Литвинова.
Ю. І. Губський постійно проводить значну науково-організаційну роботу: очолює створену за його ініціативою Проблемну експертну комісію МОЗ та НАМН України "Біологічна та медична хімія", протягом 2004-2010рр. був головою вперше створеної в нашій державі за його пропозицією та ініціативою спеціалізованої вченої ради Д 26.003.07 “Медична біохімія”. Юрій Іванович - член Наукової ради з теоретичної та профрілактичної медицини НАМН України, член редакційної колегії "Українського біохімічного журналу" і член спеціалізованої вченої ради 3 біохімії та біотехнології Інституту біохімії імені О. В. Палладіна НАН України.

Профресор Ю. І. Губський плідно розвиває актуальні медико-соціальніпроблеми паліативної тахоспісної допомоги, питання фрармакологічного знеболювання в паліативній онкології. Він $€$ одним із фундаторів і лідерів у становленні та розвитку паліативної медицини в Україні.

В останні роки колегам та друзям членакореспондента НАМН України Ю. І. Губського відома також його літературно-публіцистична творчість: книга мемуарів "Как это было. От Союза до моей Украины” (2010), збірка нарисів та літературних есе "По Сумской и дальше..." (2015), в яких автор розповідає про часи, що минули, дає свою власну етико-фрілософську оцінку неоднозначному минулому нашої країни.

Проблемнаекспертна комісія МОЗ таНАМН України “Біологічна та медичнахімія", редколегія журналу "Медична та клінічна хімія" щиро вітають Юрія Івановича Губського з ювілеєм, бажають йому міцного здоров'я і подальших творчих успіхів у його багатогранній науковопедагогічній та громадській діяльності. 